\title{
Mercury concentrations in prey fish indicate enhanced bioaccumulation in mesopelagic environments
}

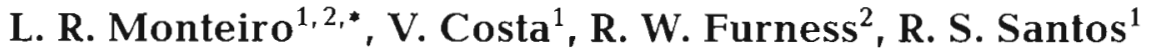 \\ 'Department of Oceanography \& Fisheries, University of the Azores, P-9900 Horta, Portugal \\ ${ }^{2}$ Applied Ornithology Unit, IBLS, University of Glasgow, Glasgow G12 8QQ, United Kingdom
}

\begin{abstract}
The detection of high concentrations of methylmercury in the sub-thermocline low oxygen seawater indicates a potential for enhanced bioaccumulation of mercury in such environments not yet explored. Here we present mercury concentrations in 8 fish species of low trophic level in relation to their vertical distribution. Fish species were selected to cover a wide range of vertical distributions, from epipelagic $(<200 \mathrm{~m})$ to mesopelagic (>300 m) environments in the sub-tropical mid-North Atlantic. Mean mercury concentrations in the study species ranged from 57 to $377 \mathrm{ppb}$ dry wt and were significantly and positively correlated with median daytime depth. Concentrations increased by 4 -fold from epipelagic to mesopelagic species with no further increases with depth among mesopelagic species down to about $1200 \mathrm{~m}$. Such enhanced mercury bioaccumulation in the marine mesopelagic compartment seems to be determined proximately by levels in food and ultimately by water chemistry that controls mercury speciation and uptake at the base of the food chain. We conclude that this is the best explanation for high and yet poorly understood mercury concentrations found in deep-sea predators.
\end{abstract}

KEY WORDS: Mercury Methylation Fish Accumulation Epipelagic - Mesopelagic

\section{INTRODUCTION}

For a number of reasons, mercury and its biogeochemical cycle are unique among metals of concern for their potentially harmful environmental effects. Mercury forms strong covalent bonds in biological systems (e.g. Lindberg 1987, WHO 1990). Unlike most other toxic metals, inorganic mercury is efficiently biotransformed into organic forms (methylmercury) in several compartments of the aquatic environment, including the water column (Topping \& Davies 1981). Mercury bioaccumulates in aquatic organisms, i.e. the concentrations in the organisms' tissues increase to a high dynamic equilibrium or even increase throughout the life span. In addition, mercury is the only metal that consistently biomagnifies through the food chain, i.e. predators accumulate higher tissue concentrations than in their food. Though factors controlling the accu-

•E-mail: monteiro@dop.uac.pt mulation of mercury in aquatic organisms are poorly understood, it is widely recognised that the accumulation of methylmercury from food or seawater is much greater than that of inorganic mercury (e.g. Boudou \& Ribeyre 1985, Canli \& Furness 1995).

Recent advances in knowledge of distribution and speciation of mercury in oceanic waters show increased concentrations of methylated mercury compounds in seawater below the thermocline (Mason \& Fitzgerald 1990, Cossa et al. 1994). Modelling studies (see Mason \& Fitzgerald 1993) indicate that dimethylmercury (DMHg) and monomethylmercury (MMHg) are produced in sub-thermocline low oxygen waters through microbial mediated methylation of reactive mercury $\left(\mathrm{Hg}_{R}\right)$ supplied by scavenging of particulate mercury from the mixed layer. The principal reactions involved are: formation of DMHg from $\mathrm{Hg}_{R}$; decomposition of $\mathrm{DMHg}$ into $\mathrm{MMHg}$; and decomposition of MMHg into elemental mercury $\left(\mathrm{Hg}^{\circ}\right)$. DMHg has been detected only in oceanic sub-thermocline waters, and 
if formation of $\mathrm{DMHg}$ is occurring at the surface (DMHg formation may occur under sub-oxic/oxic conditions; see Mason et al. 1995b), photodegradation (Sellers et al. 1996) and loss due to gas exchange result in no detectable accumulation of DMHg The long residence times of seawater away from the surface mixed zone allow DMHg to build to up to detectable levels and DMHg is the dominant methylated mercury compound in such waters (Mason et al. 1995b). DMHg does not accumulate within cells and is unstable, being the principal source of the more stable MMHg, which accumulates in anoxic waters and organisms (Bloom 1992, Mason \& Fitzgerald 1993, Mason et al. 1995b).

The prevalence of $\mathrm{MMHg}$ in sub-thermocline low oxygen oceanic waters led to the prediction of enhanced bioaccumulation of mercury by mesopelagic organisms (Mason \& Fitzgerald 1990, Cossa et al. 1994). To test this hypothesis, mercury concentrations were analysed in 8 short-lived fish species of low trophic level (essentially second order consumers) and related to their vertical distribution in the sub-tropical mid-North Atlantic Ocean.

\section{MATERIALS AND METHODS}

Fish species selected were some of the most common prey species in the local food webs and covered a wide range of vertical distributions, from epipelagic to mesopelagic environments. All samples were collected in the Azores archipelago and obtained from the fish collection at the University of the Azores Department of Oceanography and Fisheries, fishing boats and fresh fish dropped at seabird colonies. Details of sampling periods and methods of preservation, along with information on food and vertical distribution, are given in Table 1.

For each fish, total length was measured with a ruler (to $0.1 \mathrm{~cm}$ ) prior to dehydration to a constant weight in an oven at $50^{\circ} \mathrm{C}$. Homogenised samples of individual whole fish or pooled samples of similar sized fish, when concentrations in individual fish were below detection limits, were analysed for total mercury. Most ( $>90 \%$ ) mercury bioaccumulated in fish is methylmercury (as MMHg; Bloom 1992) and therefore total mercury concentrations were used to indi-

Table 1. Sampling and conservation details plus ecological characteristics (source Whitehead et al. 1986) of small epipelagic and mesopelagic fish used in this study

\begin{tabular}{|c|c|c|c|c|c|}
\hline $\begin{array}{l}\text { Family } \\
\text { Species }\end{array}$ & Sampling period & $\begin{array}{l}\text { Method of } \\
\text { preservation }\end{array}$ & Food & Vertical distribution & $\begin{array}{l}\text { Median daytime } \\
\text { depth (m) }\end{array}$ \\
\hline $\begin{array}{l}\text { Macroramphosidae } \\
\text { Snipe (trumpet) fish } \\
\text { Macroramphosus scolopa }\end{array}$ & $\begin{array}{l}\text { Aug, Nov } 1993 \\
\text { Jul } 1995 \\
\text { oax }\end{array}$ & $\begin{array}{l}\text { Frozen } \\
\text { Alcohol }\end{array}$ & $\begin{array}{l}\text { Invertebrates, } \\
\text { mainly copepods }\end{array}$ & $\begin{array}{l}\text { Juvenile }(<10 \mathrm{~cm}) \\
\text { epipelagic; adults } \\
\text { benthic, } 50-150 \mathrm{~m}\end{array}$ & 100 \\
\hline $\begin{array}{l}\text { Scombridae } \\
\text { Spanish mackerel } \\
\text { Scomber japonicus }\end{array}$ & Apr 1995 & Frozen & $\begin{array}{l}\text { Small fishes } \\
\text { and invertebrates }\end{array}$ & $\begin{array}{l}\text { Epipelagic or } \\
\text { meso-demersal } \\
\text { to } 250-300 \mathrm{~m}\end{array}$ & 150 \\
\hline $\begin{array}{l}\text { Caproidae } \\
\text { Boar fish } \\
\text { Capros aper }\end{array}$ & $\begin{array}{c}\text { Oct-Dec } 1990,1994 \\
\text { Jul } 1995\end{array}$ & $\begin{array}{l}\text { Frozen } \\
\text { Alcohol }\end{array}$ & $\begin{array}{l}\text { Copepods, } \\
\text { euphausiids } \\
\text { and molluscs }\end{array}$ & $\begin{array}{l}\text { Mesopelagic to } \\
\text { epipelagic } 40-600 \mathrm{~m} \\
\text { mainly } 100-400 \mathrm{~m}\end{array}$ & 250 \\
\hline $\begin{array}{l}\text { Carangidae } \\
\text { Blue jack mackerel } \\
\text { Trachurus picturatus }\end{array}$ & Apr, May 1995 & Frozen & Crustaceans & $\begin{array}{l}\text { Pelagic-demersal } \\
\text { down to } 370 \mathrm{~m}\end{array}$ & 200 \\
\hline $\begin{array}{l}\text { Sternoptychidae } \\
\text { Pearlsides } \\
\text { Maurolicus muellen }\end{array}$ & Sep 1979 & Alcohol $^{\circ}$ & $\begin{array}{l}\text { Copepods and } \\
\text { euphausiids }\end{array}$ & $\begin{array}{c}\text { Mesopelagic: } \\
\text { day, } 200-400 \mathrm{~m} \\
\text { night, into upper } 100 \mathrm{~m}\end{array}$ & 300 \\
\hline $\begin{array}{l}\text { Myctophidae } \\
\text { Lanternfish } \\
\text { Electrona rissoi }\end{array}$ & Jul 1995 & Alcohol & No data & $\begin{array}{c}\text { Mesopelagic: } \\
\text { day, } 225-700 \mathrm{~m} \\
\text { night, } 90-375 \mathrm{~m}\end{array}$ & 500 \\
\hline $\begin{array}{l}\text { Myctophidae } \\
\text { Lanternfish } \\
\text { Myctophum punctatum }\end{array}$ & Jul 1994 & Alcohol & $\begin{array}{l}\text { Copepods and } \\
\text { euphausiids }\end{array}$ & $\begin{array}{c}\text { Mesopelagic: } \\
\text { day, } 700-1000 \mathrm{~m}\end{array}$ & 800 \\
\hline $\begin{array}{l}\text { Myctophidae } \\
\text { Lanternfish } \\
\text { Ceratoscopelus maderen }\end{array}$ & 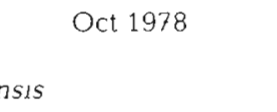 & Alcohol $^{\mathrm{d}}$ & $\begin{array}{l}\text { Copepods and } \\
\text { other planktonic } \\
\text { crustaceans }\end{array}$ & $\begin{array}{c}\text { Mesopelagic: } \\
\text { day, } 900-1500 \mathrm{~m} \\
\text { night, } 25-200 \mathrm{~m}\end{array}$ & 1200 \\
\hline
\end{tabular}


cate the whole fish burden of methylated mercury. Sample digestion and total mercury determination follow procedures described in detail elsewhere (Monteiro et al. 1995). Determinations were made by cold vapour atomic absorption spectrophotometry with a Perkin-Elmer Mercury Analyser System Coleman $50 \mathrm{~B}$. The limit of detection of the method, taken as twice the standard deviation of triplicate analysis at blank concentrations (Saltzman et al. 1983), was $10 \mathrm{ng}$, equivalent to $5 \mathrm{ng} \mathrm{g}^{-1}$ for a $2 \mathrm{~g}$ sample. Within- and between-laboratory quality control procedures were employed throughout the study period. Accuracy of the method (expressed as relative error) was within $10 \%$ and monitored throughout the study with standards of inorganic mercury, reference materials (dogfish muscle DORM 1, National Research Council of Canada, Ottawa) and participation in the hair mercury interlaboratory comparison program undertaken by Health and Welfare Canada. Precision (or reproducibility) of the method (expressed as coefficient of variation) of duplicates within and between batch was generally within the usual 10\% for total mercury determinations in biological samples (Saltzman et al. 1983). Interference on sensitivity due to matrix and pre-treatment were assessed by the method of standard additions before the wet mineralisation digestion. Recoveries of added inorganic mercury averaged $99.8 \%(\mathrm{SE}=5.6, \mathrm{n}=10)$ for reference material DORM 1 and $79.2 \%(\mathrm{SE}=2.7, \mathrm{n}=18$ ) for dehydrated whole fish. The mean recovery in the study samples differed significantly from $100 \%$ (2-tailed $t$-test for comparison with a hypothesised mean of $100 \%: t_{17}=7.61, \mathrm{p}<$ 0.0001 ) and all concentrations were corrected by this factor. Total mercury concentrations are expressed in nanograms per gram on a dry weight basis $\left(\mathrm{ng} \mathrm{g}^{-1}\right.$ or ppb dry wt). Concentrations may be converted to a fresh weight basis using as reference an overall average percentage of moisture in whole fish of $68.8 \%$ $(\mathrm{SE}=0.5 \%, \mathrm{n}=95)$.

Potential bias in mercury concentrations related with method of preservation was assessed by assigning randomly 30 fresh snipe (trumpet) fish Macroramphosus scolopax of standard size $(7$ to $9 \mathrm{~cm}$ ) to 3 treatment groups ( $\mathrm{n}=10$ each) for $8 \mathrm{wk}$ : (1) frozen at $-20^{\circ} \mathrm{C}$; (2) formaldehyde at 5\%; (3) alcohol at $70 \%$. The average mercury concentrations in the 3 treatment groups [mean \pm SE, ppb dry wt: (1) $46 \pm 8$, (2) $53 \pm 3.2$, (3) $60 \pm$ 2.8 l were not significantly different (1-way ANOVA, $F_{1,27}=2.35, \mathrm{p}=0.11$ )

Statistical analysis followed standard procedures (Zar 1984). Data were tested for goodness of fit to a normal distribution using Kolmogorov-Smirnov 1-sample test and requirements of homogeneity of variances were determined using Levene test. Where appropriate, parametric or non-parametric tests were employed.

\section{RESULTS}

Mean mercury concentrations in the 8 study species ranged from 57 to 377 ppb dry wt (Table 2). Mean mercury concentrations and median daytime depth (Fig. 1) show a significant positive correlation $\left(\mathrm{r}_{\mathrm{s}}=0.88, \mathrm{t}_{6}=\right.$ $4.56, p<0.005)$. Mercury levels increase by 4 -fold from

Table 2. Total length and total mercury concentrations for the small epipelagic and mesopelagic fish samples used in this study. Length and mercury values are mean $\pm \mathrm{SE}$ and range below

\begin{tabular}{|lccc|}
\hline Species & $\mathrm{n}$ & $\begin{array}{c}\text { Total length } \\
(\mathrm{cm})\end{array}$ & $\begin{array}{c}\mathrm{Hg} \\
(\mathrm{ppb}, \mathrm{dry} w \mathrm{t})\end{array}$ \\
\hline Macroramphosus & 42 & $8.0 \pm 0.2$ & $57 \pm 3$ \\
scolopax & & $5.7-11.4$ & $14-115$ \\
Scomber & 4 & $26.0 \pm 1.7$ & $91 \pm 12$ \\
japonicus & & $21.5-28.5$ & $71-122$ \\
Capros & 19 & $8.7 \pm 0.6$ & $147 \pm 24$ \\
aper & & $4.6-13.0$ & $32-331$ \\
Trachurus & 20 & $16.8 \pm 0.7$ & $149 \pm 27$ \\
picturatus & & $9.8-21.7$ & $26-469$ \\
Maurolicus & 11 & $4.6 \pm 0.1$ & $343 \pm 23$ \\
muelleri & & $4.1-5.2$ & $251-446$ \\
Electrona & 10 & $8.1 \pm 0.3$ & $323 \pm 45$ \\
rissoi & & $6.8-9.0$ & $145-533$ \\
Myctophum & 6 & $7.7 \pm 0.2$ & $320 \pm 35$ \\
punctatum & & $7.0-8.3$ & $150-367$ \\
Ceratoscopelus & 14 & $6.8 \pm 0.1$ & $377 \pm 9$ \\
maderensis & & $6.5-7.5$ & $318-423$ \\
& & & \\
\hline
\end{tabular}

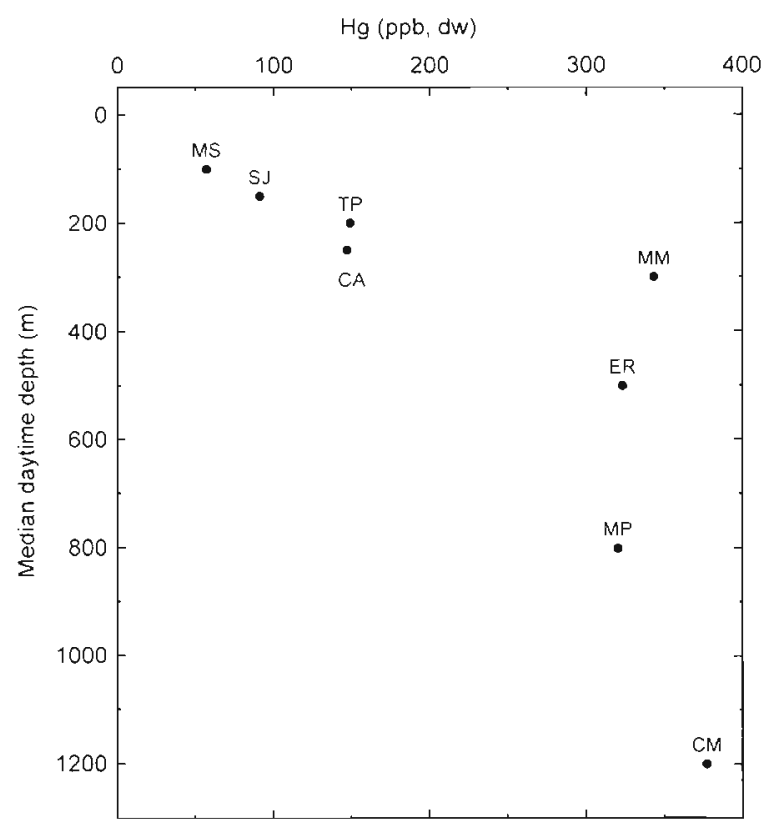

Fig. 1. Relationship between mean mercury concentrations and median daytime depth for 8 fish species in the Azores. Species codes are the initials of scientific names given in Table 1 


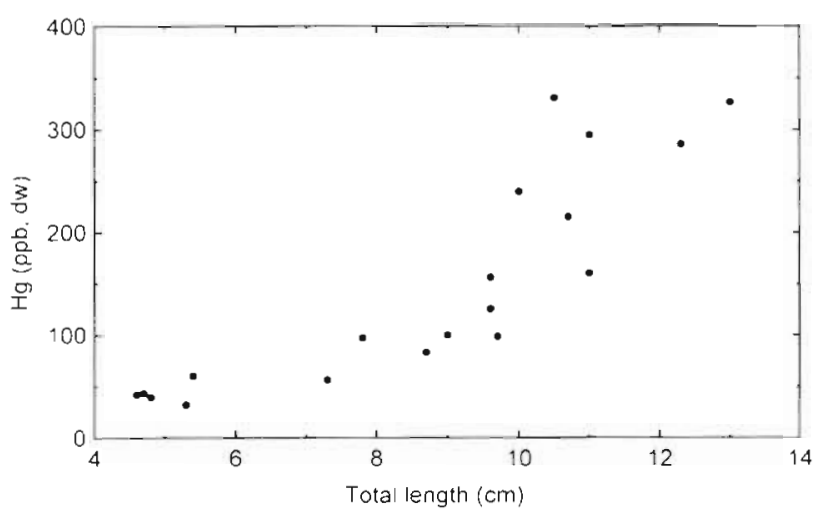

Fig. 2. Capros aper. Relationship between mercury concentrations and total length in boar fish from the Azores

epipelagic $(100$ to $150 \mathrm{~m})$ to mesopelagic $(300$ to $1200 \mathrm{~m}$ ) species. Intermediate levels were observed in species occurring in the transition (median depths of 200 to $250 \mathrm{~m}$ ) between epipelagic and mesopelagic environments. Concentrations did not vary among mesopelagic species (Kruskal-Wallis, $H_{3, n=41}=2.08, \mathrm{p}=$ 0.56 ).

Mercury concentrations are independent of fish size for snipe (trumpet) fish $\left(r_{s}=-0.027, t_{40}=0.18, p=0.86\right.$ ) and blue jack mackerel Trachurus picturatus $\left(\mathrm{r}_{\mathrm{s}}=\right.$ $-0.21, t_{18}=0.92, p=0.37$ ) but increase significantly with total length for boar fish Capros aper $\left(\mathrm{r}_{\mathrm{s}}=0.93\right.$, $t_{17}=10.27, p<0.0001$; Fig. 2). Such correlation is thought to illustrate an increase in mercury concentrations with depth in boar fish, because the second half of the size range, which occurs typically below $200 \mathrm{~m}$ (Holzlöhner \& Orlowski 1986), showed concentrations typical of mesopelagic species while the first half showed concentrations typical of epipelagic species.

\section{DISCUSSION}

Because of human health concerns (Clarkson 1990), mercury accumulation in commercial predatory fish has been studied thoroughly and concentrations have been found to increase with species trophic level and longevity, as well as fish age (e.g. Riisgård \& Hansen 1990, Monteiro et al. 1991, Joiris et al. 1995). Information on mercury accumulation in non-commercial small prey fish of low trophic level is scanty. Results from this study indicate that vertical distribution is a major factor contributing to inter-specific and boar fish intra-specific variations in mercury levels. Age-dependent accumulation of mercury in these short-lived species (overall less than 2 yr, e.g. Isidro 1990, Linkowski et al. 1993, except for Spanish mackerel) is unlikely to account for the observed 4 -fold increase in mercury concentrations between the epipelagic and meso- pelagic fish species. Such an increase seems to arise from the widespread and remarkably elevated availability of monomethylmercury (MMHg) in sub-thermocline waters (North Atlantic, equatorial Pacific and Mediterranean; Mason \& Fitzgerald 1993, Cossa et al. 1994, Mason et al. 1995b) which generally occur below $200 \mathrm{~m}$, as in the study region (Gould 1985, M. Alves pers. comm.). Moreover, uniform mercury concentrations observed among mesopelagic fish species with varying depth ranges (300 to $1200 \mathrm{~m}$; this study) are consistent with absence of major variations of $\mathrm{MMHg}$ concentrations in sub-thermocline ocean waters (Mason \& Fitzgerald 1990, Cossa et al. 1994, Mason et al. 1995 b).

Results from this study confirm the predicted enhanced mercury bioaccumulation in sub-thermocline low oxygen waters. This begs an appraisal of the relative importance of uptake from food or water in this environment. The biomagnification of mercury resembles that of hydrophobic organic trace pollutants rather than that of ionic metals and it is generally thought to result from the lipid solubility of $\mathrm{MMHg}$. This seems an inadequate explanation for 2 reasons: (1) unlike other hydrophobic compounds, $\mathrm{MMHg}$ in fish resides in protein rather than in fat tissue (Bloom 1992); (2) neutral complexes of inorganic mercury are as soluble as their MMHg analogues and accumulate passively in phytoplankton (Mason et al. 1995a). However, differences in partitioning within phytoplankton cells between inorganic (which is principally membrane bound) and MMHg (which accumulates in the cytoplasm) lead to a greater assimilation of $\mathrm{MMHg}$ during zooplankton grazing (Mason et al. 1995a). Thus, most of the discrimination between inorganic and $\mathrm{MMHg}$ seems to occur during trophic transfer at the base of the food chain while the major enrichment factor is between water and phytoplankton (Mason et al. 1995a). As a result, enhanced mercury bioaccumulation in fish in sub-thermocline waters would be determined proximately by levels in food and ultimately by water chemistry which controls mercury speciation and uptake at the base of the food chain. This is supported by the much higher efficiency of $\mathrm{MMHg}$ uptake from ingested food $(70 \%)$ than from water passed over the gills (10\%; Phillips \& Bulher 1978). Mesopelagic fish and certain prey co-occur over much of the depth range during the day, as both migrate into the epipelagic zone at night (e.g. Hopkins \& Gartner 1992, Perissinotto \& McQuaid 1992), and thus enhanced trophic transfer of mercury to mesopelagic fish may occur during daylight hours and at night.

Enhanced bioaccumulation of mercury in mesopelagic organisms of low trophic level arising from sub-thermocline reservoirs of $\mathrm{MMHg}$ (this study) is the best explanation for high and yet poorly understood 
mercury concentrations found in deep-sea predators (e.g. Phillips 1980, Renzoni et al. 1991). This poses an additional problem regarding the human and environmental health risks of mercury (e.g. WHO 1990, Fitzgerald \& Clarkson 1991) due to the increasing importance of deep-sea marine organisms as sources of protein for humans (Pitcher \& Hart 1987). Furthermore, the global increase in mercury contamination over the last century (Mason et al. 1994) is affecting the marine ecosystems (Slemr \& Langer 1992. Thompson et al. 1992, Rolfhus \& Fitzgerald 1995) and is amplified in mesopelagic environments (Monteiro 1996).

Acknowledgements. This research was supported by Junta Nacional de Investigaçāo Científica through grant BD/2289/ 92-IG to L.R.M. and research contract STRDB/C/MAR/228/ 92. We thank Eduardo Esteves, Telmo Gomes, Filipe Porteiro and Pedro Afonso for fish identification, and Mário Laranjo and Luis Pires for valuable assistance with sample preparation and mercury determinations.

\section{LITERATURE CITED}

Bloom N (1992) On the chemical form of mercury in edible fish and marine invertebrate tissue. Can J Aquat Sci 49 : 1010-1017

Boudou A, Ribeyre F (1985) Experimental study of trophic contamination of Salmo gairdneri by two mercury compounds $-\mathrm{HgCl}_{2}$ and $\mathrm{CH}_{3} \mathrm{HgCl}$ - analysis at the organism and organ levels. Wat Air Soil Pollut 26:137-148

Canli M, Furness RW (1995) Mercury and cadmium uptake from seawater and from food by the Norway lobster Nephrops norvegicus. Environ Toxicol Chem 14:819-828

Clarkson TW (1990) Human health risks from methylmercury in fish. Environ Toxicol Chem 9:957-961

Cossa D, Martin JM, Sanjuan J (1994) Dimethylmercury formation in the Alboran Sea. Mar Pollut Bull 28:381-384

Fitzgerald WF, Clarkson TW (1991) Mercury and monomethylmercury: present and future concerns. Environ Health Perspect 96:159-166

Gould WJ (1985) Physical oceanography of the Azores front. Prog Oceanogr 14:167-190

Holzlöhner S, Orlowski A (1986) Hydroacoustic stock estimation and biological results on the Josephine Bank in August 1984. ICES CM 1986/H:57

Hopkins TL, Gartner JV (1992) Resource-partitioning and predation impact of a low-latitude myctophid communty. Mar Biol 114:185-197

Isidro HA (1990) Age and growth of Trachurus picturatus (Bowdich, 1825) (Teleostei: Carangidae) from the Azores. Arquipél Cien Nat 8:45-54

Joiris CR, Ali IB, Holsbeek L, Bossicart M, Tapia G (1995) Total and organic mercury in Barents Sea pelagic fish. Bull Environ Contam Toxicol 55:674-681

Lindberg S (1987) Group report: mercury. In: Hutchinson TC, Meema HM (eds) Lead, mercury, cadmium and arsenic in the environment. John Wiley \& Son Ltd, Chichester, p 17-33

Linkowski TB, Radtake RL, Lenz PH (1993) Otolith microstructure, age and growth of two species of Ceratoscopelus (Osteichthyes: Myctophidae) from the eastern North Atlantic. J Exp Mar Biol Ecol 167:237-260

Mason RP. Fitzgerald WF (1990) Alkylmercury species in the equatorial Pacific. Nature 347:457-459
Mason RP, Fitzgerald WF (1993) The distribution and biogeochemical cycling of mercury in the equatorial Pacific Ocean. Deep Sea Res I 40:1897-1924

Mason RP, Fltzgerald WF, Morel FMM (1994) The biogeochemical cycling of elemental mercury: anthropogenic influences. Geochim Cosmochim Acta 58:3191-3198

Mason RP, Reinfelder JR, Morel FMM (1995a) Broaccumulation of mercury and methylmercury. Wat Air Soil Pollut 80 : 915-921

Mason RP, Rolfhus KR, Fitzgerald WF (1995b) Methylated and elemental mercury cycling in surface and deep ocean waters of the North Atlantic. Wat Air Soil Pollut 80:665-677

Monteiro LR (1996) Seabirds as monitors of mercury contamination in the Portuguese Atlantic. PhD thesis, University of Glasgow

Monteiro LR, Furness RW, del Nevo AJ (1995) Mercury levels in seabirds from the Azores, mid-North Atlantic. Arch Environ Contam Toxicol 28:304-309

Monteiro LR, Isidro EJ, Lopes HD (1991) Mercury content in relation to sex, size, age and growth in two scorpionfish (Helicolenus dactylopterus and Pontinus kuhlii) from Azorean waters. Wat Air Soil Pollut 56:359-367

Perissinotto R, McQuaid CD (1992) Land-based predator impact on vertically migrating zooplankton and micronekton advected to a Southern Ocean archipelago. Mar Ecol Prog Ser 80:15-27

Phillips DJH (1980) Quantitative aquatic biological indicators: their use to monitor trace metal and organochlorine pollution. Applied Science Publishers Ltd, London

Phillıps GR, Buhler DR (1978) The relative contributions of methylmercury from food or water to the rainbow trout (Salmo gairdneri) in a controlled laboratory environment. Trans Am Fish Soc 107:853-861

Pitcher TJ, Hart PJB (1987) Fisheries ecology. Croom Helm, London

Renzoni A, Chemello G, Gaggi C, Bargagli R, Bacci E (1991) Methylmercury in deep-sea organisms from the Mediterranean. MAP Tech Rep Ser 59:303-318

Riisgård HU, Hansen S (1990) Biomagnification of mercury in a marine grazing food-chain: algal cells Phaeodactylum tricornutum, mussels Mytilus edulis and flounders Platichthys flesus studied by means of a stepwise-reduction-CVAA method. Mar Ecol Prog Ser 62:259-270

Rolfhus KR, Fitzgerald WF (1995) Linkages between atmospheric mercury deposition and the methylmercury content of marine fish. Wat Air Soil Pollut 80:291-297

Saltzman BE, Yeager DW, Meiners BG (1983) Reproducibility and quality control in the analysis of brological samples for lead and mercury. Am Ind Hyg Assoc J 44:263-267

Sellers P. Kelly CA, Rudd JWM, MacHutchon AR (1996) Photodegradation of methylmercury in lakes. Nature 380:694-697

Slemr F, Langer E (1992) Increase in global atmospheric concentrations of mercury inferred from measurements over the Atlantic Ocean. Nature 35j:434-436

Thompson DR, Furness RW, Walsh PM (1992) Historical changes in mercury concentrations in the marine ecosystem of the north and north-east Atlantic ocean as indicated by seabird feathers. J Appl Ecol 29:79-84

Topping G, Davies IM (1981) Methylmercury production in the marine water column. Nature 290:243-244

Whitehead PJP, Bauchot ML, Hureau JC, Nielsen J, Tortonese $E$ (eds) (1986) Fishes of the North-eastern Atlantic and the Mediterranean. UNESCO. Paris

WHO (1990) Environmental health criteria 101 methylmercury. World Health Organisation, Geneva

Zar (1984) Biostatistical analysis, 2nd edn. Prentice Hall International, Englewood Clıffs, NJ 